\title{
Legen som forvaltar av rettslege reglar
}

Engelsk oversettelse på www.tidsskriftet.no

Rettsvitskapen er eit akademisk fag som vi som ikkje er juristar bør vere varsame med å utfordre i si grunnlagstenking. Respekten for fagleg, disiplinbasert kunnskap tilseier det. Like fullt er det slik i vår tid at klinisk arbeid ikkje berre byggjer på medisinsk kunnskap og samhandling med pasienten. Avgjerder i klinisk praksis er faktisk sett også ofte rettslege avgjerder.

Når sjukehuslegen fattar vedtak om at ein pasient har rett til nødvendig helsehjelp ut frå tilvising frå fastlegen, er det ei avgjerd med rettsverknad for pasienten. Allmennlegen si vurdering av kva lækjemiddel som skal nyttast ved behandlinga av hypertensjon, endar ofte opp i ei avgjerd som medfører at pasienten får rettskrav på dekning av visse utgifter ved behandlinga. Vurderinga av kva opplysningar som skal førast i pasientjournalen, byggjer på helsepersonellet si forståing og tolking av dei relativt detaljerte forskriftskrava til journalføring. Ikkje minst skal helsepersonellet handle i samsvar med lovkravet til fagleg forsvarleg verksemd i møte med einkvar pasient. Dette tilseier at helsearbeidarar flest, og ikkje minst legar, må ha eit visst minstemål av kunnskap om rettslege arbeidsmåtar. Rettsvitskap og medisin er akademiske tradisjonar som har det til felles at dei møter praktiske problemstillingar. Men måten dei møter desse på er svært så ulike. Olav Molven kallar juristen sin arbeidsmåte for normrasjonell (1). Då er det slik at ein let den praktiske utfordringa møte ei lovgjeving som er sett på førehand. Så resonnerer ein seg fram til kva som er rett avgjerd. Han omtalar vidare helsearbeidaren sin arbeidsmåte som formålsrasjonell. Legen lèt seg styre av det som best gagnar pasienten. Desse to avgjerdslogikkane kan stundom kome i konflikt med kvarandre.

I denne utgåva av Tidsskriftet er det ein artikkel som syner dette (2). Forfattarane har ved bruk av konstruerte pasienthistorier sett på korleis ulike grupper av legar praktiserer retningslinene om bruk av ultralydundersøking i svangerskapet (3). Dei har vidare samanlikna legane sine vurderingar med vurderingane til ei mindre gruppe saksbehandlarar i Helsedirektoratet. Dei påviser at legane i liten grad held seg til retningslinene. Dei seier også at desse blir tolka ulikt av legane og forvaltarane. Sjølv om dette ikkje er uventa funn, og sjølv om funna ikkje stammar frå reell praksis, er det god grunn til å drøfte dei nærare.

Dei seinare tiåra har vi opplevd ein svær auke i rettslege krav til ytinga av helsetenester. På mange måtar er dette eit gode, fordi det har gitt pasientane tydelegare rettar og meir føreseielege forhold. Men auken i rettskrav har ført til ei innskrenking av det skjønnet som helsearbeidarane kan utøve i møte med pasientane (4). Av omsyn til rettstryggleiken for pasientane, mellom anna for å sikre fråvere av usakleg skilnadsbehandling, og for å ha ei viss styring med ressursbruken i helsetenesta, har ein spedd på med ulike former for retningsliner og rettleiingar frå forvaltninga si side. Det er då interessant å sjå nærare på kva rettsleg status slike dokument har; altså kor bindande dei er for medisinsk praksis og legane si skjønnsutøving. Helse- og omsorgsdepartementet har uttala seg om det i eit brev til KS (5). Der peikar dei på at det sjølvsagt er krava i lovgjevinga, altså lovar og forskrifter, som er bindande. Men dei viser vidare til at nasjonale faglege retningsliner vil vere eit naturleg grunnlag for vurderinga av kva som i gitte tilfelle er å sjå på som fagleg forsvarleg. I brevet seier dei vidare at en nasjonal faglig retningslinje er faglig normerende, mens en veileder inneholder råd og veiledning. Dei slår fast at når tenesteytarane vel ein praksis som i vesentleg grad er avvikande frå det som blir føreslege i retningsliner eller vegleiarar, bør det skje ut frå ei konkret og godt grunngjeven vurdering.
For kliniske praktikarar meiner eg at dette kan kokast ned til følgjande minikurs i juridisk metode:

- Der reglar i lov- eller forskriftstekst stiller eintydige krav eller gir spesifikke løysingar, må legen følgje desse. Då må legen ta normrasjonelle avgjerder. Døme på slike, kan vere reglane om journalføring og meldeplikter.

- Der reglane opnar for helsefaglege vurderingar, kan legen leggje den formålsrasjonelle avgjerdsprosessen til grunn. Utfordringa ligg då i å vise at formålsrasjonaliteten har eit godt medisinsk grunnlag. Ved offentleg tenesteyting må ein dessutan vere trygg på at ein ikkje driv med skilnadsbehandling ved å gje tilbodet til nokon, men ikkje til andre utan at det er saklege grunnar for det. Det beste dømet på slike reglar er kravet om forsvarleg verksemd.

Undersøkinga til Kjerstine Røe og medarbeidarar tyder på at det ikkje er fleire faglege retningsliner åleine som skal til for å sikre etterleving av sentrale rettslege krav. Legane legg stor vekt på følgjene for pasientane i avgjerdene sine. Ei god helselovgjeving må difor byggje på realistiske helsefaglege og samfunnsmessige føresetnader. Då kan regelverket gje ein god struktur til tenesteytinga og sikre føreseielege rammer for både pasientar og tenesteytarar. Sjølvsagt må lovgjevinga utfyllast av gode døme på korleis ho kan etterlevast i praksis. Det er der retningsliner og vegleiarar kjem inn. For å verke i praksis, kan det vere grunn til å sjå på om nettopp slike dokument skal vere staden der den normrasjonell og den formålsrasjonelle avgjerdslogikken møtest. Då må dei utformast på helsefaglege premissar og ikkje berre framstå som juridiske tolkingar av regelverket. I det tidlegare nemnde brevet frå Helse- og omsorgsdepartementet er dei på sporet av nettopp dette ved å seie at departementet legger videre til grunn at sentrale fagmiljøer og så vel brukere som kommunesektoren aktivt skal involveres i utarbeidelsen av dokumentene.

Dette har då også Helsedirektoratet lagt til grunn ved utarbeidinga av prioriteringsrettleiingane dei seinare åra. Det skal bli spennande å sjå om denne framgangsmåten sikrar ei etterleving av faglege styringssignal frå sentralt hald.

\section{Geir Sverre Braut}

gsb@helsetilsynet.no

Geir Sverre Braut (f. 1955) er assisterande direktør i Statens helsetilsyn og førstelektor ved Høgskolen Stord/Haugesund.

Forfattar har fylt ut ICMJE-skjemaet og oppgjev følgjande interessekonfliktar: Han er embetsmann.

\footnotetext{
Litteratur

1. Molven O. Helse og jus. En innføring for helsepersonell. Oslo: Gyldendal, 2009.

2. Røe K, Salvesen KÄ, Eggebø TM. Blir retningslinjene for fosterdiagnostisk ultralyd fulgt? Tidsskr Nor Legeforen 2012; 132: 1603-6.

3. Veiledende retningslinjer for bruk av ultralyd i svangerskapet. IS-23/2004. Oslo: Helsedirektoratet, 2004.

4. Syse A. Pasientrettighetsloven med kommentarer. Oslo: Gyldendal, 2009.

5. Brev av 8. mai 2012 til Kommunesektorens interesse- og arbeidsgiverorganisasjon. Om den juridiske og faglige status rundskriv, retningslinjer

og veiledere har for kommunesektoren på helse- og omsorgsområdet. Oslo: Helse og omsorgsdepartementet, 2012. www.helsetilsynet.no/upload/regelverk/ runskriv_status_HOD_KS_2012.pdf (16.6.2012).
} 